\title{
DISCURSO DE ABERTURA DA VI REUNIÃO DA ABAVE
}

FORTALEZA/CE, 31 DE AGOSTO, O1 E 02 DE SETEMBRO DE 2011.

“AVALIAÇÃO E O DIREITO À QUALIDADE DA EDUCAÇÃO” Senhoras e Senhores

Iniciamos hoje a VI Reunião da ABAVE. Uma programação variada e rica congrega mais de 600 participantes.

Estudantes, professores e pesquisadores de várias universidades, gestores da educação pública das diferentes esferas governamentais, docentes e gestores das escolas públicas e privadas, gestores de fundações de apoio à educação pública, membros das instituições especializadas em avaliação educacional, enfim, um conjunto de competências que, a cada encontro, demonstra maior capacidade de retratar a educação brasileira e apontar caminhos para superar os seus grandes desafios.

Podemos vislumbrar no movimento da Abave a possibilidade de unir forças, interesses, competências e grande disposição para estimular a verdadeira reforma pela qual anseia a educação no Brasil. É nossa tarefa a realização de estudos e pesquisas que sustentem políticas educacionais adequadas, garantindo as mudanças necessárias e urgentes na escola brasileira, principalmente na escola pública, em nome de um nobre ideal: 
garantir o direito a aprender e promover a igualdade de oportunidades.

O crescimento do atendimento à demanda educacional nos últimos anos foi acompanhado pelo desenvolvimento dos instrumentos de avaliação da educação básica como prática corrente dos sistemas de ensino.

A Abave se forma nesse contexto.

Responde a esse movimento propondo a integração das competências que foram se formando na área da avaliação educacional. E mais, busca o debate constante e a universalização do conhecimento produzido.

Observando o conjunto das políticas educacionais, proposto com base no desenvolvimento dos procedimentos de avaliação, assistimos a uma mudança profunda nos padrões de gestão da educação pública, cada vez mais a favor de um compromisso de todos com os resultados educacionais. A favor da criança e dos jovens brasileiros.

Se, por um lado o avanço científico e a tecnologia permitiram criar sistemas de avaliação cada vez mais precisos e sofisticados, o que esses sistemas estão a nos dizer sobre a qualidade da educação brasileira?

Os resultados das avaliações atestam, de modo geral, a baixa qualidade do ensino oferecido em nossas escolas. Observamos a existência de grande número de crianças e adolescentes que, por razões relacionadas às dificuldades de aprendizagem, aliadas às precárias condições de vida, são submetidas a reprovações contínuas que resultam no abandono da escola. São muitas as crianças e muitos os jovens que não encontram na escola o que seria necessário para o seu crescimento, desenvolvimento e conquista da sua autonomia.

Por isso, costumamos dizer que avaliar a educação é testar a eficácia de um direito fundamental. $O$ direito à educação não se resume à vaga na escola, ele só se realiza quando garante a inclusão de todos na plenitude da vida social, cultural e política do país.

Daí o nosso tema desta VI Reunião da Abave: "AVALIAÇÃO E O DIREITO À QUALIDADE DA EDUCAÇÃO”.

Na verdade, é possível dizer hoje que a exigência de uma educação de qualidade - direito de nossas crianças, de nossos jovens e de todos os brasileiros -, não pode ser mais formulada,

11 Est. Aval. Educ., São Paulo, v. 23, n. 51, p. 10-14, jan./abr. 2012 
dispensando os processos de avaliação. Sem os dados e informações por eles produzidos, não há como realizar um debate público consistente e adotar ações orientadas para a democratização do ensino e melhoria de sua qualidade. Quanto mais essas informações passarem a ser utilizadas pelos gestores educacionais, professores, pais e alunos, maiores serão as condições de se estruturar um planejamento condizente com as reais necessidades de nossas escolas, atendendo à sua diversidade e exigência.

Por isso, mais importante do que comparar os resultados alcançados por regiões, estados, municípios e escolas, é refletir coletivamente, elaborar diagnósticos e propor as ações adequadas a cada realidade. As avaliações oferecem sempre um rico material de discussão, a ser cotejado pelo projeto pedagógico de cada escola e a ser consultado pelos gestores em todos os níveis de governo. Ele provoca a discussão sistemática do currículo e a adoção de estratégias pedagógicas e políticas educacionais destinadas a promover o sucesso dos processos de ensino e de aprendizagem e a igualdade das oportunidades educacionais.

As evidências resultantes dos dados coletados pelas avaliações trazem à tona os grandes desafios a serem enfrentados pelos sistemas de ensino. Imediatamente, identificamos três deles.

O primeiro diz respeito à alfabetização. Em média, 30\% das crianças no quarto ou quinto ano de escolarização não podem ser consideradas alfabetizadas. Este índice passa da metade dos alunos, quando se põem em perspectiva níveis de letramento mais adequados à continuidade dos estudos no ensino fundamental. É importante, portanto, a avaliação contínua dos anos iniciais do processo de alfabetização. É nessa perspectiva que devemos entender os programas estaduais de avaliação da alfabetização e a Provinha Brasil, que foram implementados com a ideia de produzir um diagnóstico apropriado dos seus alunos e, com orientação adequada, tomar as providências necessárias, colocando em cena programas complementares de apoio ao letramento, como acontece em Minas Gerais, Ceará, Espírito Santo, Pernambuco e Mato Grosso do Sul, dentre outros estados também pioneiros na implantação de programas de avaliação da alfabetização.

Outro desafio importante: é certo que as desigualdades brasileiras incidem fortemente nas oportunidades educacionais 
de crianças e jovens. Contudo, as disparidades regionais não devem servir de justificativa para a admissão de padrões de desempenho inaceitáveis. Em uma unidade da Federação se constata que $30 \%$ das crianças com quatro anos de escolaridade são, para todos os efeitos práticos, analfabetas. Em outra, este percentual se eleva para $60 \%$. Esses números não podem perder o seu verdadeiro sentido. Não importa onde nasceu o brasileiro, o acesso à leitura e à escrita deve ser garantido a todos, sem distinção.

Por último, a educação matemática e científica proporcionada aos nossos alunos é muito deficiente. Para ficar em um exemplo, há um largo conjunto de competências associadas à resolução de problemas algébricos e geométricos, cujo desenvolvimento sequer chega a ser observado para os alunos do ensino médio.

Estes desafios se somam a muitos outros, fundamentais para a qualidade de nossa educação e a promoção da equidade. E talvez um deles seja o combate sem trégua à indiferença ou ao ceticismo diante do quadro educacional brasileiro, ou à premissa de que para a maioria dos brasileiros bastam apenas alguns rudimentos de escolarização. Por esta razão é preciso conceber políticas que incentivem os profissionais da educação que querem fazer a diferença, políticas que combatam os cenários tão frequentes de paralisia e inércia. $\mathrm{E}$ isso não se faz só com recursos e orçamentos, mas com ideias generosas e democráticas, bons programas de ensino e propostas curriculares inovadoras, padrões de desempenho bem definidos e atenção redobrada com a formação e valorização do professor.

E nessa direção, gostaria de ressaltar que a Abave, pela ação de seus pesquisadores, tem hoje uma larga experiência, que pode ser transformada em base para a sugestão de políticas públicas destinadas a fazer diferença para a nossa educação. Certamente, a Abave dará vários passos a mais no que tem feito até agora, tornando-se mais ainda uma parceira propositiva e efetiva da sociedade e dos governos no enfrentamento dos nossos imensos desafios educacionais em busca da concretização do nosso nobre ideal: toda criança e jovem brasileiro na escola e com direito a educação de qualidade.

Ao encerrar minha fala com a proposição de um novo passo em nosso caminho, gostaríamos de externar os nossos 
sinceros agradecimentos aos parceiros e colaboradores (Avalia Assessoria Educacional; CAEd/UFJF; Fundação Carlos Chagas; Fundaçao Cesgranrio; Fundação Lemann; Fundação Unibanco; Inep/MEC e Secretaria de Estado da Educação do Ceará) que contribuíram para a realização desse evento, registrados com a entrega da placa com os seguintes dizeres:

Os gestores que fazem a história são aqueles que, com determinação, coragem e espírito público, marcam sua atuação. Manifestamos nossos sinceros agradecimentos pela confiança e pela parceria na realização da VI Reunião ABAVE/2011, contribuindo, assim, com o debate em torno do tema Avaliação e Qualidade da Educação.

\section{Lina Kátia Mesquita de Oliviera}

Diretora Presidente da ABAVE

Associação Brasileira de Avaliação Educacional

linakatia@caed.ufj.br 